\title{
The Coat Protein Gene is Essential for the Systemic Infection of Cucumber Mosaic Virus in Cucumis figarei at a High Temperature*
}

\author{
Hiromasa SAITOH**, Masayuki FujIWARA**, Satoshi T. OHKI** \\ and Takeshi OSAKI**
}

\begin{abstract}
Systemic infection of cucumber mosaic virus (CMV) in Cucumis figarei at high temperature was investigated using reassortants and chimeric RNAs. Three CMV strains of pepo-, SO-, MY17- and Y-CMV were used : pepo-, SO- and MY17-CMV systemically infected $C$. figarei at $36^{\circ} \mathrm{C}$, whereas Y-CMV did not as previously described. Inoculation with in vitro transcripts from biologically active cDNA clones of Y-CMV and pepo-CMV RNAs 1, 2 and 3 indicated that only the inocula containing pepo-CMV RNA 3 induced systemic infection at $36^{\circ} \mathrm{C}$, suggesting that the resistance against systemic infection by Y-CMV and its breakage by pepo-CMV were mapped to CMV RNA 3. Inoculation with transcripts from the cDNA clones of Y-CMV RNAs 1, 2 and RNA 3 of SO-CMV or MY17-CMV provoked systemic infection at high temperature, indicating that the systemic infection by SO-CMV or MY17-CMV was also mapped to RNA 3. Analysis with chimeras constructed between CDNA clones of Y-CMV and pepo-CMV RNA 3 showed that the resistance and resistance breakage were mapped to the coat protein gene on CMV RNA 3. Comparison of the nucleotide sequence of pepo-, SO- and MY17-CMV RNA 3 with that of Y-CMV RNA 3 revealed that the coat protein of Y-CMV differs from those of pepo-, SO- and MY17-CMV in four amino acids at positions 17 (Leu to Pro), 25 (Ser to Pro), 28 (Ser to Ala) and 129 (Ser to Pro). These results suggested that all or some of the four amino acids play an important role in determining long-distance movement of $\mathrm{CMV}$ in $C$. figarei at a high temperature.
\end{abstract}

(Received August 28, 1998 ; Accepted January 8, 1999)

Key words : cucumber mosaic virus, Cucumis figarei, virus resistance, long-distance movement, high temperature, coat protein gene.

\section{INTRODUCTION}

Many reports have indicated that the inability of a virus to infect a particular plant host results from lack of cell-to-cell or long-distance movement of the virus. Such movement of plant viruses is frequently mediated by viral gene products ${ }^{4,9,26)}$.

In the case of cucumber mosaic virus (CMV), all five gene products were reported to be involved in virus movement. The five CMV genes were expressed with distinct functions from three genomic and two subgenomic RNAs. RNAs 1 and 2 encode the $1 \mathrm{a}$ and the $2 \mathrm{a}$ proteins, respectively, involved in replication of the viral genome ${ }^{11,17)}$, which also plays some role in virus movement ${ }^{8,12}$. The product of an additional gene on RNA 2, known as the $2 \mathrm{~b}$ gene, also influences virus movement in a host-specific manner ${ }^{6}$. The two gene products encoded by dicistronic RNA 3 are required for infection in plants. Genomic RNA 3 encodes a nonstructural protein of the $3 \mathrm{a}$ movement protein (MP) along with the coat protein $(\mathrm{CP})$ that is translated from subgenomic mRNA of RNA 4. The 3a MP is required for cell-to-cell movement ${ }^{3,5,15)}$ and possibly for longdistance movement $t^{1,15}$. The $\mathrm{CP}$ is also needed for efficient cell-to-cell movement in all hosts tested ${ }^{2,3,29)}$ and is a determinant for restriction of systemic spread of the virus $^{22,31)}$.

Cucumis figarei, a wild African relative of Cucumis melo (melon), is highly resistant to several viruses, including CMV. A comparative analysis of replication and movement of $\mathrm{CMV}$ in $C$. figarei and $C$. melo indicated that the resistance of $C$. figarei to $\mathrm{CMV}$ might primarily be caused by the inhibition of virus movement via both cell-to-cell and long-distance ${ }^{23}$. Furthermore, we demonstrated that the systemic resistance in $C$. figarei to $\mathrm{Y}$ and two other CMV strains was sustained at a high temperature but the resistance to pepo-, SO- and MY17-

\footnotetext{
* This study was supported in part by the Grant-in-Aid for Scientific Research from the Ministry of Education, Science, Sports and Culture of Japan (No. 06404009).

** College of Agriculture, Osaka Prefecture University, Sakai 599-8531, Japan大阪府立大学農学部
} 
CMV was breakable at that temperature ${ }^{25)}$.

The objective of this work is to clarify the mechanism for the resistance and long-distance movement of CMV in $C$. figarei plants at a high temperature. In this paper we report that the $\mathrm{CP}$ gene on CMV RNA 3 is responsible for the systemic infection and the resistance breakage in $C$. figarei at a high temperature $\left(36^{\circ} \mathrm{C}\right)$.

\section{MATERIALS AND METHODS}

Plants, CMV strains, CMV inoculation and detection of $\boldsymbol{C M V}$ in tissues C. figarei plants were grown in a growth chamber at $25^{\circ} \mathrm{C}$ with a 12 -h light/ 12-h dark cycle. Four CMV strains in subgroup I, YCMV, pepo-CMV ${ }^{18,24)}$, SO-CMV ${ }^{24,25)}$ and MY17-CMV ${ }^{24,25)}$ were used. Three expanded true leaves of $C$. figare $i$ were inoculated 30 days after sowing with purified CMV at a concentration of $2 \mathrm{mg} / \mathrm{ml}$ in $100 \mathrm{mM}$ phosphate buffer at $\mathrm{pH}$ 7.0. The plants were then grown in growth chambers at the determined temperatures. CMV in tissues was detected by tissue printing and northern blotting as previously described ${ }^{23,25)}$. In both cases, the ${ }^{32} \mathrm{P}$-labeled RNA probe complementary to the $3^{\prime} 200$ nucleotides of pepo-CMV RNA 3 was used ${ }^{25)}$.

cDNA clones for $Y$-, pepo-, SO- and MY17-CMV $\boldsymbol{R N A s}$ Full-length cDNA clones of Y-CMV RNAs 1 (Y1 : pCY1-T7), 2 (Y2 : pCY2-T7) and 3 (Y3 : pCY3-T7) ${ }^{29)}$ were obtained from C. Masuta, Hokkaido University.

To construct the cDNA clone of pepo-CMV RNA 1, two overlapping fragments were synthesized. The $3^{\prime}$ proximal 1541-3361 fragment was amplified by $5^{\prime}$ CCGGATCCTGGTCTCCTTTTGGAGGCCC-3' and 5 $^{\prime}$ CGCCTAATACGACTCACTATAGTTTTATTTACAAGAGCG-3'. This fragment was then digested with $E c o$ RI and $B a m \mathrm{HI}$, and ligated into the same restriction sites of pCRII (Invitrogen), creating pCP13IB. The $5^{\prime}$ proximal 1-1620 fragment amplified by $5^{\prime}$-CCGGATCCTAATACGACTCACTATAGTTTTATTTACAAGAGCG-3' and 5' -GCGGATCCCGGATGATATCACGTCCC-3' was digested with Bam HI and ligated into the Bam HI site of pCRII, creating pCP15BV. pCP1TP1 (P1) containing full-length cDNA of pepo-CMV RNA 1 was obtained by ligating an EcoRI fragment of pCP15BV into the same restriction site of pCP13IB.

Full-length cDNA clone of pepo-CMV RNA 2 (P2: pCP2TP1) was prepared by the method described elsewhere ${ }^{24)}$. cDNA clones for pepo-CMV RNA 3 (P3 : pCP3TP2), SO-CMV RNA 3 (S3 : pCS3TP1) and MY17CMV RNA 3 (M3 : pCM3TP3) were also used ${ }^{24)}$.

Construction of reassortants between pepo- and $\boldsymbol{Y}-\boldsymbol{C M V} ; \quad Y-C M V$ and MY17- or SO-CMV pCP1TP1 (P1), pCP2TP1 (P2) and pCP3TP2 (P3) were linearized with $B a m \mathrm{HI}$, whereas pCY1-T7 (Y1), pCY2T7 (Y2) and pCY3-T7 (Y3) were linearized with NotI. The RNA transcripts from the full-length cDNA clones of pepo- and Y-CMV RNAs 1-3 were combined to form the parental RNA. The RNA 3s transcribed from EcoRI-linearized pCS3TP1 (S3) or pCM3TP3 (M3) were combined with RNA transcripts from pCY1-T7 (Y1) and pCY2-T7 (Y2) to form the parental RNA. Individual RNAs of CMV strains Y- (Y), pepo- (P), SO- (S) and MY17- (M) are designated as 1, 2, and 3 ; e.g., Y1Y2P3 contains RNA 1 plus 2 of Y-CMV and RNA 3 of pepoCMV. These reassortants were then propagated in tobacco plants (Nicotiana tabacum cv. Xanthi nc), because $C$. figarei can be infected only with CMV at a high concentration. The reassortants purified from systemically infected leaves were used for inoculating $C$. figarei.

Construction of RNA 3 chimeras between $Y$ - and pepo- $\boldsymbol{C M V}$ RNA 3 chimeras between Y-and pepoCMV were constructed as follows. The cDNA clone of pepo-CMV RNA 3 (P3: pCP3TP2) was cut with XbaI and HindIII, blunt-ended with T4 DNA polymerase and then self-ligated, creating P33 (pCP3TP3). The first pair of reciprocal chimeras was constructed using the common SalI site, located 1297 nucleotides from the $5^{\prime}$ end of Y-CMV RNA 3 and 1294 nucleotides from the $5^{\prime}$ end of pepo-CMV RNA 3, and the SacI cloning site in Y3 or P33. These chimeras were constructed by exchanging SalI/SacI fragments, creating YP (pCY3P3Sal) and PY (pCP3Y3Sal). The third chimera was constructed using SalI and the NruI site which was located at nucleotide 1377 in Y-CMV RNA 3 and nucleotide 1374 in pepo-CMV

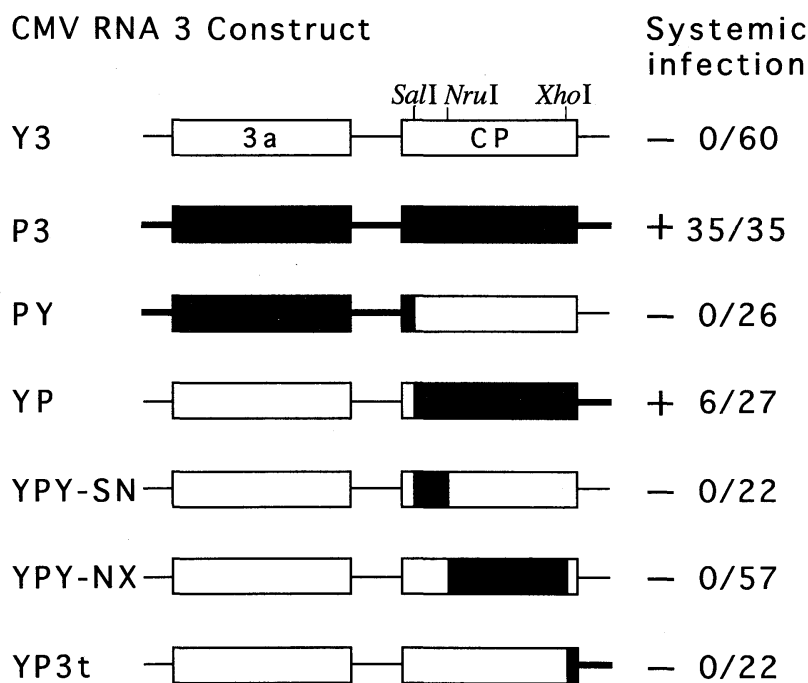

Fig. 1. Systemic infectivity of reconstructed cucumber mosaic virus (CMV) on Cucumis figarei at $36^{\circ} \mathrm{C}$. CMV contained RNAs 1 and 2 from Y-CMV (Y1 and $\mathrm{Y} 2$ ) and RNA 3 derived from Y-CMV (Y3), pepo-CMV (P3) or chimeras formed between cDNA clones of Y-CMV RNA 3 (open rectangles) and pepo-CMV RNA 3 (filled rectangle), using the restriction sites SalI, NruI or XhoI. The infectivity of virus containing the wild-type or chimeric RNA 3 is indicated by "+" or "-" with the number of systemically infected plants over the number of inoculated plants. Systemic infectivity was assayed by symptoms and verified by tissue printing and northern blotting analysis. 
RNA 3, and by exchanging SalI/NruI fragment of Y3 with that of P3, creating YPY-SN (pCY3PcpSN). The fourth chimera was constructed using $N r u \mathrm{I}$ and the XhoI site which was located at nucleotide 1839 in Y-CMV RNA 3 and nucleotide 1836 in pepo-CMV RNA 3 , and by exchanging $N r u \mathrm{I} / \mathrm{XhoI}$ fragment of $\mathrm{Y} 3$ with that of P3, creating YPY-NX (pCY3PcpNX). The fifth chimera was constructed by exchanging $\mathrm{XhoI} / \mathrm{SacI}$ fragment of Y3 with that of P3, creating YP3t (pCY3P3Xho) (Fig. 1).

Y1, Y2 and PY were linearized with NotI, Y3, YP, YPY-SN, YPY-NX, YP3t with EcoRI and P3 with Bam HI. The RNA transcripts from Y1, Y2 and fulllength cDNA clones of each RNA 3 were combined to form pseudorecombinants which were then propagated in tobacco plants as described previously. The purified reassortants were used as the inocula. The preserved nucleotide sequence for each RNA construct was further confirmed for RNA 3 recovered from the purified reassortants.

Comparative studies on the nucleotide sequence among CMV isolates were assisted by computer software program GENETYX (Software Development).

\section{RESULTS AND DISCUSSION}

\section{Mapping resistance breakage to CMV RNA 3}

Whereas Y-, pepo-, SO- and MY17-CMV locally infect C. figarei at $24^{\circ} \mathrm{C}$, only pepo-, SO- and MY17-CMV systemically infect the plant at $36^{\circ} \mathrm{C}^{25)}$. To map the resistance against systemic infection by $\mathrm{Y}-\mathrm{CMV}$ and its breakage by some CMV strains in $C$. figarei at $36^{\circ} \mathrm{C}$, systemic infectivity of the reassortants was tested.

Table 1. Development of systemic symptoms in $C$. figarei infected with $10 \mathrm{CMV}$ reassortants at different temperatures

\begin{tabular}{ccc}
\hline \hline \multirow{2}{*}{$\begin{array}{c}\text { CMV } \\
\text { reassortants }\end{array}$} & \multicolumn{2}{c}{ Incubation temperature $\left({ }^{\circ} \mathrm{C}\right)$} \\
\cline { 2 - 3 } & 24 & \multicolumn{1}{c}{$0 / 15$} \\
\hline Y1Y2Y3 & $0 / 15^{\text {b) }}$ & $0 / 15$ \\
Y1P2Y3 & $0 / 15$ & $0 / 15$ \\
Y1Y2P3 & $0 / 15$ & $15 / 15$ \\
Y1P2P3 & $0 / 15$ & $9 / 15$ \\
P1Y2Y3 & $0 / 15$ & $0 / 15$ \\
P1P2Y3 & $0 / 15$ & $0 / 15$ \\
P1Y2P3 & $0 / 15$ & $8 / 15$ \\
P1P2P3 & $0 / 15$ & $15 / 15$ \\
Y1Y2S3 & $0 / 22$ & $16 / 22$ \\
Y1Y2M3 & $0 / 18$ & $11 / 20$ \\
\hline
\end{tabular}

a) Individual RNAs of CMV strains $\mathrm{Y}-(\mathrm{Y})$, pepo- (P), SO(S) and MY17-(M) are designated as 1, 2, and 3; e.g., Y1Y2P3 contains RNA 1 plus 2 of Y-CMV and RNA 3 of pepo-CMV.

b) Number of plants systemically infected/number of plants tested at 14 days after inoculation. Data reflect infectivity ascertained by symptoms and verified by tissue printing and northern blotting analysis of noninoculated upper leaves.
All C. figarei plants inoculated with reassortants between $\mathrm{Y}$ - and pepo-CMV and incubated at $24^{\circ} \mathrm{C}$ or $36^{\circ} \mathrm{C}$ showed bright yellow chlorotic spots on the inoculated leaves. None of the plants inoculated with reassortants and incubated at $24^{\circ} \mathrm{C}$ developed systemic symptoms on the upper leaves. Furthermore, none of the plants inoculated with Y1Y2Y3, Y1P2Y3, P1Y2Y3 and P1P2Y3 and incubated at $36^{\circ} \mathrm{C}$ developed systemic symptoms on the upper leaves. On the other hand, all or most of the plants inoculated with Y1Y2P3, Y1P2P3, P1Y2P3 and $\mathrm{P} 1 \mathrm{P} 2 \mathrm{P} 3$ incubated at $36^{\circ} \mathrm{C}$ showed yellow chlorotic spots on the upper leaves (Table 1). The systemic infectivity of the reassortants containing $\mathrm{P} 3$ was verified by detecting viral RNAs with tissue printing and northern blotting from the noninoculated upper leaves (data not shown). These results indicated that the viral factor involved in the resistance against systemic infection by $\mathrm{Y}-\mathrm{CMV}$ and its breakage by pepo-CMV at $36^{\circ} \mathrm{C}$ was located in CMV RNA 3.

C. figarei inoculated with reassortants containing RNA 3 from the SO- and MY17-CMV (Y1Y2S3 and Y1Y2M3) and incubated at $36^{\circ} \mathrm{C}$ also showed prominent chlorotic spots on the upper leaves (Table 1). These results further suggested that the resistance breakage of C. figarei at $36^{\circ} \mathrm{C}$ to some $\mathrm{CMV}$ strains was determined by CMV RNA 3.

There are some reports that temperature effects on CMV infection were variable and dependent on host plant and virus strains. On the cultivar-specific temperature sensitivity, Roossink (1991) ${ }^{21)}$ examined the temperature effect on CMV infection in muskmelon (Cucumis melo cv. Iroquis), using a fast strain of Fny and slow strain of Sny. The pseudorecombination between the two strains showed that the temperature sensitivity was mapped to Sny-CMV RNA 1. There are several works reporting that one or more gene products are needed for the long-distance movement of CMV in specific cucurbit species $^{3,8,14,15,21,27)}$. Nevertheless, our results indicated that CMV RNA 3, encoding the 3a protein and the CP, is solely essential for the systemic infection of CMV in C. figarei at $36^{\circ} \mathrm{C}$.

\section{Localization of resistance breakage within the $3^{\prime}$ half of the pepo-CMV RNA 3}

To delimit which region within CMV RNA 3 determines the systemic infection, five chimeric recombinants were constructed between the cDNA clones of $\mathrm{Y}$ - and pepo-CMV RNA 3. Infectivity of the viruses with the chimeric recombinants was shown in Fig. 1. The purified virus containing the $3^{\prime}$ region of pepo-CMV RNA 3 (YP) induced systemic symptoms, whereas the reciprocal chimera (PY) did not. Furthermore, none of the plants inoculated with the reassortants containing RNA 3 transcripts from YPY-SN, YPY-NX and YP3t developed systemic symptoms at $36^{\circ} \mathrm{C}$. Systemic infection of $C$. figarei plants inoculated with reassortants containing P3 and YP were further analyzed by tissue printing (Fig. 2). These results suggested that two or more regions of the SalI/NruI, the NruI/XhoI and the region from the XhoI 


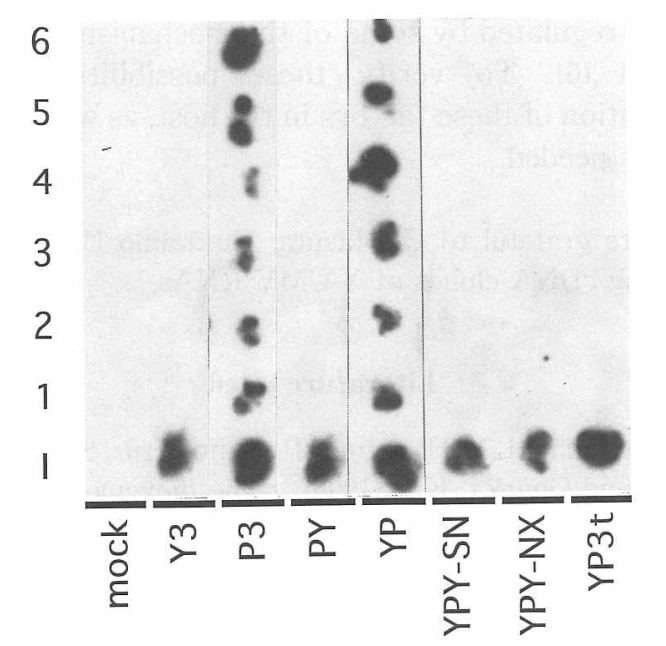

Fig. 2. Analysis by tissue printing of CMV RNAs in leaves of $C$. figarei inoculated with the reconstructed $\mathrm{CMVs}$ and incubated at $36^{\circ} \mathrm{C}$. The inocula contained RNAs 1 and 2 from Y-CMV ( $\mathrm{Y} 1$ and $\mathrm{Y} 2$ ) and RNA 3 derived from $\mathrm{Y}-\mathrm{CMV}$ (Y3), pepo-CMV (P3) or chimeras formed between cDNA clones of Y-CMV RNA 3 and pepo-CMV RNA 3 as indicated in Fig. 1. Sample leaves from individual plants for each reconstructed CMV were analyzed at 7 days after inoculation by the ${ }^{32} \mathrm{P}$-labeled RNA probe complementary to the $3^{\prime} 200$ nucleotides of pepoCMV RNA 3. I, inoculated leaves; 1-6, noninoculated upper leaves in descending order from top; mock, leaves treated with buffer.

site to the $3^{\prime}$ end were necessary for the resistance breakage.

\section{Localization of specific CP sequences involved in} resistance breakage

We determined the nucleotide sequence of RNA 3 of pepo-, SO- and MY17-CMV and compared them to that of Y-CMV RNA $3^{24)}$. There are some differences in the nucleotide sequence among pepo-, SO- and MY17-CMV RNA 3, though all three strains can systemically infect C. figarei at $36^{\circ} \mathrm{C}$. Among the predicted 279 amino acids of Y-, pepo-, SO- and MY17-CMV 3a protein, only one amino acid at position 238 was different: Val for pepoCMV, and Ala for Y-, SO-, MY17-CMV.

Several findings demonstrate that changes in the sequence of the $3 \mathrm{a}$ protein can affect the ability to regulate the long-distance movement of CMV strains. The restricted movement in cucurbit hosts has been mapped to two sequence changes in the codons of amino acids 51 and 240 of the Sny-CMV 3a gene ${ }^{14)}$. Sequences between amino acids 209 and 236 contain a domain critical for function for the 3 a protein, and amino acids 237-279 are not required for the movement-associated functions of the 3 a protein ${ }^{15}$. We found one amino acid substitution among the four CMV strains at position 238 of the $3 \mathrm{a}$ protein in the region not required for movement.

Figure 3 shows an alignment of the predicted amino
Amino Acid Positions

\begin{tabular}{|c|c|c|c|c|c|}
\hline & \multicolumn{3}{|c|}{$\begin{array}{c}\mathrm{NruI} \\
\perp\end{array}$} & \multicolumn{2}{|c|}{$\begin{array}{c}\text { XhoI } \\
\mid\end{array}$} \\
\hline & \multicolumn{5}{|c|}{ Coat Protein Gene } \\
\hline & 8172528 & 47 & 65 & 129 & 205 \\
\hline Y-CMV & S LS S & $\mathrm{A}$ & $\mathrm{K}$ & $\mathbf{s}$ & $\mathrm{E}$ \\
\hline Pepo-CMV & $\mathrm{G} \mathbf{P} \boldsymbol{P A}$ & $S$ & $\mathrm{~K}$ & $\mathbf{P}$ & $E$ \\
\hline SO-CMV & $S \mathbf{P P A}$ & $\mathrm{S}$ & $\mathrm{K}$ & $\mathbf{P}$ & $E$ \\
\hline MY17-CMV & S P P A & $\mathrm{A}$ & $R$ & $\mathbf{P}$ & 1 \\
\hline
\end{tabular}

Fig. 3. Difference in amino acid sequences in coat protein gene for Y-, pepo-, SO- and MY17-CMV. Encoded amino acids which differ from Y-CMV are indicated with the relative positions. The three restriction sites are also indicated as Fig. 1.

acid sequence of $\mathrm{Y}-$, pepo-, SO- and MY17-CMV CP. Among 218 amino acids of the CP, changes were found at eight positions. Four amino acids at positions 17, 25, 28 and 129 were different between Y-CMV and pepo-, SO-, MY17-CMV (Fig. 3, shown in bold). These results suggested that the changes in the CP gene of Y-CMV RNA 3 at four positions 17 (Leu to Pro), 25 (Ser to Pro), 28 (Ser to Ala) and 129 (Ser to Pro) were possibly required for long-distance movement of $\mathrm{CMV}$ in $C$. figarei at a high temperature. We cannot deny involvement of the 3 ' end sequence as yet. Whether all four amino acids are responsible for the movement remains unclear. We have so far known that CMV containing the Y-CMV RNA 3 derivatives with only one amino acid substitution (17 Pro, 25 Pro, 28 Ala and 129 Pro) could not systemically infect at $36^{\circ} \mathrm{C}$ (unpublished data).

Wikoff et al. $(1997)^{33)}$ suggested that the $\mathrm{N}$-terminal 22 amino acids of CMV CP featuring a high density of Arg residues, known as the internal R-domain, may interact with the viral RNA in either assembling or stabilizing CMV particles. Kaplan et al. (1998) ${ }^{16)}$ also demonstrated that the deletion of some of the basic amino acids within the amino-terminal 26 amino acids of the CMV CP (amino acids 15-40) had an effect on virion stability as well as RNA-binding stability by the CP. N-terminal amino acids of Brome mosaic virus ${ }^{20)}$ and Alfalfa mosaic virus $^{32)}$, which are classified in Bromoviridae along with CMV, are required for regulating virus-host interaction. Therefore, the first two amino acids (17 Pro and 25 Pro) or three amino acids (17 Pro, 25 Pro or $28 \mathrm{Ala}$ ) in the CP are possibly important for the virus movement.

Another amino acid substitution was Ser (Y-CMV) to Pro (pepo-, SO- and MY17-CMV) at amino acid 129 (Fig. 3). The amino acid at position 129 is reported to influence symptom expression ${ }^{28,30)}$, aphid transmissibility ${ }^{19)}$, or a break in host resistance : changes in the CP gene of M-CMV RNA 3 at both positions 129 
(Leu to Pro) and 162 (Thr to Ala) were required to overcome resistance against M-CMV in maize ${ }^{22)}$. Thus, the amino acid difference at this region in the $\mathrm{CP}$ may have some effect on restricting movement of Y-CMV at a high temperature in $C$. figarei.

Possible mechanisms for the break in resistance

$\mathrm{CMV}$ requires its $\mathrm{CP}$ for both cell-to-cell and longdistance movement. The $\mathrm{CP}$ also has host-specific determinants for systemic spread ${ }^{13,27,31)}$. Y-CMV as well as pepo-CMV cannot infect $C$. figarei systemically at $24^{\circ} \mathrm{C}$, whereas pepo-CMV infects systemically at $36^{\circ} \mathrm{C}^{25)}$. In this study, we suggested that the CMV CP gene had an active role in the long-distance movement of CMV infection in $C$. figarei, which occurred only at a high temperature $\left(36^{\circ} \mathrm{C}\right)$. This CMV-C. figarei relationship is considered as a non-necrotic resistance ${ }^{23)}$, in which the entrance or exit of viruses through the bundle-sheath/ phloem parenchyma barrier is regulated ${ }^{7,10)}$. In a separate study, we demonstrated that pepo-CMV was detectable in the vascular system as well as in the parenchyma cells of inoculated leaves of $C$. figarei incubated at $36^{\circ} \mathrm{C}$ but not at $24^{\circ} \mathrm{C}$ and that Y-CMV was detected only in the parenchyma and bundle-sheath cells at both temperatures (unpublished data). Recently, a model was presented that CMV moved into minor sieve elements as a ribonucleoprotein (RNP) complex that contained the viral RNA, the $\mathrm{CP}$ and the $3 \mathrm{a} \mathrm{MP}^{1)}$. In this model, a host factor in addition to the $\mathrm{CP}$ may be needed for forming a stable RNP complex. Both the R-domain ${ }^{16,33)}$ and the amino acid at position $129^{19)}$ in CP may affect its ability to interact with the host factor. All four changed amino acids in pepo-, SO- and MY17-CP are hydrophobic, whereas the three changed amino acids in Y-CP are not (Fig. 3). This difference probably modifies the stability of the CPs.

Taken together, we speculate that the major mechanisms for the resistance breakage are as follows: (1) The host factor for viral movement is induced in the $C$. figarei plant. (2) The movement of $\mathrm{Y}$ - as well as pepo$\mathrm{CMV}$ is inhibited at $24^{\circ} \mathrm{C}$, because another host factor that prevented the interaction between the $\mathrm{CP}$ and the host factor or the formation of the RNP complex is induced in the plant at $24^{\circ} \mathrm{C}$. (3) The second host factor, suppressed by heat shock at $36^{\circ} \mathrm{C}$, enables pepo-CP to interact with the host factor or to form the RNP complex. The CP-host factor interaction or RNP-formation is not launched for Y-CMV, on the other hand, because the Y-CP accumulation in the inoculated leaves is notably low (unpublished data). (4) The host factor for the viral movement is induced only at a high temperature, which is effective for pepo-CMV. It does not work with Y-CMV because of the CP shortage. (5) The pepo$\mathrm{CP}$ specifically elicits host responses necessary for viral movement. (6) The pepo-CP and Y-CP are structurally different, because the amino acids in the R-domain and at position 129 are important for conformation. Only pepo-CP is stable enough to be recognized by the host factor at $36^{\circ} \mathrm{C}$. The long-distance movement of $\mathrm{CMV}$ may be regulated by some of the mechanisms of (1), (2), (3) and (6). To verify these possibilities, further clarification of these factors in the host, as well as in the virus, is needed.

We are grateful to C. Masuta, Hokkaido University for providing cDNA clones of Y-CMV RNAs.

\section{Literature cited}

1. Blackman, L.M., Boevink, P., Santa Cruz, S., Palukaitis, P. and Oparka, K.J. (1998). The movement protein of cucumber mosaic virus traffics into sieve elements in minor veins of Nicotiana clevelandii. Plant Cell 10 : 525537.

2. Boccard, F. and Baulcombe, D.C. (1993). Mutational analysis of cis-acting sequences and gene function in RNA 3 of cucumber mosaic virus. Virology 193: 563578.

3. Canto, T., Prior, D.A.M., Hellwald, K-H., Oparka, K.J. and Palukaitis, P. (1997). Characterization of cucumber mosaic virus. IV. Movement protein and coat protein are both essential for cell-to-cell movement of cucumber mosaic virus. Virology 237 : 237-248.

4. Carrington, J.C., Kasschau, K.D., Mhajan, S.K. and Schaad, M.C. (1996). Cell-to-cell and long-distance transport of viruses in plants. Plant Cell $8: 1669-1681$.

5. Ding, B., Li, Q., Nguyen, L., Palukaitis, P. and Lucas, W. J. (1995). Cucumber mosaic virus 3a protein potentiates cell-to-cell trafficking of CMV RNA in tobacco plants. Virology 207 : 345-353.

6. Ding, S.-W., Li, W.-X. and Symons, R.H. (1995). A novel naturally occurring hybrid gene encoded by a plant RNA virus facilitates long distance virus movement. EMBO J. 14 : 5762-5772.

7. Dufour, O., Palloix, A., Selassie, K.G., Pochard, E. and Marchoux, G. (1989). The distribution of cucumber mosaic virus in resistant and susceptible plants of pepper. Can. J. Bot. 67 : 655-660.

8. Gal-On, A., Kaplan, I., Roossinck, M.J. and Palukaitis, P. (1994). The kinetics of infection of zucchini squash by cucumber mosaic virus indicate a function for RNA 1 in virus movement. Virology $205: 280-289$.

9. Gilbertson, R.L. and Lucas, W.J. (1996). How do viruses traffic on the 'vascular highway'? Trends Plant Sci. 1 : 260-268.

10. Goodrick, B.J., Kuhn, C.W. and Hussey, R.S. (1991). Restricted systemic movement of cowpea chlorotic mottle virus in soybean with non-necrotic resistance. Phytopathology 81 : 1426-1431.

11. Hayes, R.J. and Buck, K.W. (1990). Complete replication of a eukaryotic virus RNA in vitro by a purified RNA-dependent RNA polymerase. Cell 63 : 363-368.

12. Hellwald, K.-H. and Palukaitis, P. (1995). Viral RNA as a potential target for two independent mechanisms of replicase-mediated resistance against cucumber mosaic virus. Cell 83 : 937-946.

13. Hilf, M.E. and Dawson, W.O. (1993). The tobamovirus capsid protein functions as a host-specific determinant of long-distance movement. Virology 193 : 106-114.

14. Kaplan, I.B., Gal-On, A. and Palukaitis, P. (1997). Char- 
acterization of cucumber mosaic virus. III. Localization of sequences in the movement protein controlling systemic infection in cucurbits. Virology $230: 343-349$.

15. Kaplan, I.B., Shintaku, M.H., Li, Q., Zhang, L., Marsh, L. E. and Palukaitis, P. (1995). Complementation of virus movement in transgenic tobacco expressing the cucumber mosaic virus 3a gene. Virology 209 : 188-199.

16. Kaplan, I.B., Zhang, L. and Palukaitis, P. (1998). Characterization of cucumber mosaic virus. V. Cell-to-cell movement requires capsid protein but not virions. Virology $246: 221-231$.

17. Nitta, N., Takanami, Y., Kuwata, S. and Kubo, S. (1988). Inoculation with RNAs 1 and 2 of cucumber mosaic virus induces viral RNA replicase activity in tobacco mesophyll protoplasts. J. Gen. Virol. 69 : 2695-2700.

18. Osaki, T. and Shobara, K. (1973). A strain of cucumber mosaic virus isolated from Cucurbita pepo. Proc. Kansai P1. Prot. 15 : 135-136 (in Japanese).

19. Perry, K., Zhang, L. and Palukaitis, P. (1998). Amino acid changes in the coat protein of cucumber mosaic virus differently affect transmission by the aphids Myzus persicae and Aphis gossypii. Virology 242 : 204-210.

20. Rao, A.L.N. and Grantham, G.L. (1996). Molecular studies of bromovirus capsid protein. II. Functional analysis of the amino-terminal arginine-rich motif and its role in encapsidation, movement, and pathology. Virology 226 : 294-305.

21. Roossink, M.J. (1991). Temperature-sensitive replication of cucumber mosaic virus in muskmelon (Cucumis melo cv. Iroquois), maps to RNA 1 of a slow strain. J. Gen. Virol. 72 : 1747-1750.

22. Ryu, K.H., Kim, C.-H. and Palukaitis, P. (1998). The coat protein of cucumber mosaic virus is a host range determinant for infection of maize. Mol. Plant-Microbe Interact. $11: 351-357$.

23. Saiga, T., Fujiwara, M., Saitoh, H., Ohki, S. T. and Osaki, T. (1998). Comparative analysis for replication and movement of cucumber mosaic virus in Cucumis figarei and C. melo. Ann. Phytopathol. Soc. Jpn. 64 : 255263.

24. Saitoh, H., Fujiwara, M., Kobori, T., Ohki, S.T. and Osaki, T. (1999). Nucleotide sequence analysis for RNA 3 of pepo-, SO- and MY17-strains of Cucumber mosaic virus and its comparison with Y-strain. Sci. Rep. Coll. Agric. Osaka Pref. Univ. 51 : (in press).

25. Saitoh, H., Saiga, T., Ohki, S.T. and Osaki, T. (1998). Systemic resistance in Cucumis figarei to some strains of cucumber mosaic virus is breakable at high temperature. Ann. Phytopathol. Soc. Jpn. 64 : 194-197.

26. Séron, K. and Haenni, A.-L. (1996). Vascular movement of plant viruses. Mol. Plant-Microbe Interact. 9 : 435-442.

27. Shintaku, M. and Palukaitis, P. (1990). Genetic map- ping of cucumber mosaic virus. In Viral Genes and Plant Pathogenesis (Pirone, T.P. and Shaw, J.G. eds.), Springer-Verlag, New York, pp. 156-164.

28. Shintaku, M.H., Zhang, L. and Palukaitis, P. (1992). A single amino acid substitution in the coat protein of cucumber mosaic virus induces chlorosis in tobacco. Plant Cell 4 : 751-757.

29. Suzuki, M., Kuwata, S., Kataoka, J., Masuta, C., Nitta, N. and Takanami, Y. (1991). Functional analysis of deletion mutants of cucumber mosaic virus RNA3 using an in vitro transcription system. Virology $183: 106-113$.

30. Suzuki, M., Kuwata, S., Masuta, C. and Takanami, Y. (1995). Point mutations in the coat protein of cucumber mosaic virus affect symptom expression and virion accumulation in tobacco. J. Gen. Virol. 76 : 1791-1799.

31. Taliansky, M.E. and García-Arenal, F. (1995). Role of cucumovirus capsid protein in long-distance movement within the infected plant. J. Virol. 69 : 916-922.

32. van der Vossen, E.A.G., Neeleman, L. and Bol, J.F. (1994). Early and late functions of alfalfa mosaic virus coat protein can be mutated separately. Virology 202 : 891-903.

33. Wikoff, W.R., Tsai, C.J., Wang, G., Baker, T.S. and Johnson, J.E. (1997). The structure of cucumber mosaic virus: cryoelectron microscopy, X-ray cryostallography, and sequence analysis. Virology $232:$ 91-97.

\section{和 文 摘 要}

斉藤宏昌・藤原正幸・大木 理・尾崎武司：Cucumis figarei の高温条件でのキュウリモザイクウイルスによる全身感染には 外被たんぱく質遺伝子が必要である

Cucumis figarei の高温条件でのキュウリモザイクウイルス (CMV) による全身感染のウイルス側の因子を調べるために, reassortment 実験とキメラRNA による実験を行った。高温条 件で全身感染する pepo-CMV の RNA 1-3 の感染性 cDNA ク ローン由来の RNA と, 全身感染しない Y-CMV RNA 1-3 の cDNA 由来の RNA とを組み合わせて接種したところ, $36^{\circ} \mathrm{C}$ 条 件では pepo-CMV RNA 3 を含む組み合わせのみで全身感染が 認められたことから，全身感染にかかわる因子は CMV RNA 3 にあることがわかった。全身感染する SO-と MY17-CMVの RNA 3 の cDNA クローン由来 RNA と Y-CMV RNA 1-2 の 接種でも全身感染したことから，これらの系統についても全身 感染にかかわる因子は CMV RNA 3 にあることが示された。ま た，Y-CMV RNA 3 と pepo-CMV RNA 3 を部分的に組み換 えたキメラ RNA による実験で, 全身感染にかかわる因子が CP 遺伝子にあることが示された。さらに, pepo-, SO-, MY17-CMV の RNA 3 の塩基配列を Y-CMV RNA 3 と比較した結果, Y-と pepo-, SO-, MY17-の CP 領域には 17 (Leu $\rightarrow$ Pro), 25 ( $\mathrm{Ser} \rightarrow$ Pro), 28 (Ser $\rightarrow$ Ala), 129 (Ser $\rightarrow$ Pro)番目の 4 箇所のアミノ 酸相違部位が認められた。これらのアミノ酸が高温条件におけ る CMV の長距離移行に重要と考えられる。 